\title{
Non-philosophy and Derrida
}

\begin{tabular}{|c|c|}
\hline $\begin{array}{l}\text { Author: } \\
\text { Johann-Albre }\end{array}$ & ht Meylahn ${ }^{1}$ (D) \\
\hline $\begin{array}{l}\text { Affiliation: } \\
{ }^{1} \text { Department } \\
\text { Theology, FacL } \\
\text { and Religion, } \\
\text { Pretoria, Preto }\end{array}$ & $\begin{array}{l}\text { f Practical } \\
\text { Ity of Theology } \\
\text { Iniversity of } \\
\text { ria, South Africa }\end{array}$ \\
\hline $\begin{array}{l}\text { Project Resea } \\
\text { Project Leader } \\
\text { Project Numb }\end{array}$ & $\begin{array}{l}\text { ch Registration: } \\
: \text { J.A. Meylahn } \\
\text { er: } 02187133\end{array}$ \\
\hline $\begin{array}{l}\text { Description: } \\
\text { This research } \\
\text { research proje } \\
\text { practical postt } \\
\text { theology as pi } \\
\text { in response to } \\
\text { of lived religio } \\
\text { contemporary } \\
\text { Africa', directe } \\
\text { Johann Meyla } \\
\text { Practical Theo } \\
\text { Theology and } \\
\text { University of }\end{array}$ & $\begin{array}{l}\text { is part of the } \\
\text { ct, 'Towards a } \\
\text { oundational } \\
\text { bblic theology } \\
\text { the challenges } \\
\text { in } \\
\text { Southern } \\
\text { d by Prof. Dr } \\
\text { hn, Department } \\
\text { logy, Faculty of } \\
\text { Religion, } \\
\text { retoria. }\end{array}$ \\
\hline $\begin{array}{l}\text { Correspondin } \\
\text { Johann-Albrec } \\
\text { johann.meyla }\end{array}$ & $\begin{array}{l}\text { gauthor: } \\
\text { ht Meylahn, } \\
\text { hn@up.ac.za }\end{array}$ \\
\hline $\begin{array}{l}\text { Dates: } \\
\text { Received: } 26 \mathrm{~J} \\
\text { Accepted: } 01 \mathrm{~S} \\
\text { Published: } 12\end{array}$ & $\begin{array}{l}\text { uly } 2019 \\
\text { Sept. } 2019 \\
\text { Nov. } 2019\end{array}$ \\
\hline $\begin{array}{l}\text { How to cite th } \\
\text { Meylahn, J-A., } \\
\text { 'Non-philosop } \\
\text { Derrida', HTS } \\
\text { Studies/Theol } \\
\text { 75(4), a5665. } \\
\text { 10.4102/hts.v }\end{array}$ & $\begin{array}{l}\text { is article: } \\
2019, \\
\text { hy and } \\
\text { eoologiese } \\
\text { gical Studies } \\
\text { https://doi.org/ } \\
75 i 4.5665\end{array}$ \\
\hline $\begin{array}{l}\text { Copyright: } \\
\text { @ 2019. The } A \\
\text { Licensee: AOS } \\
\text { is licensed unc } \\
\text { Creative Comr } \\
\text { Attribution Lic }\end{array}$ & $\begin{array}{l}\text { IS. This work } \\
\text { Ier the } \\
\text { nons } \\
\text { ense. }\end{array}$ \\
\hline Read online: & \\
\hline 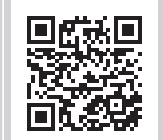 & $\begin{array}{l}\text { Scan this QR } \\
\text { code with your } \\
\text { smart phone or } \\
\text { mobile device } \\
\text { to read online. }\end{array}$ \\
\hline
\end{tabular}

This study brings the thoughts of Derrida into conversation with François Laruelle's nonphilosophy or non-standard philosophy. Laruelle argued that Derrida is a philosopher of difference, thereby grouping Derrida together with Heidegger and Deleuze as philosophers of difference. The argument of this article is to explore Derrida's work, bringing it into conversation with Laruelle's non-philosophy and non-standard philosophy. This article is focussed specifically on Derrida's democracy to come in line with Laruelle's democracy of thought. The context of this discussion is the end of philosophy or the closure of philosophy, and the opening of this closure for a democracy is yet to come - or whether the ideas of the end of philosophy or the closure of philosophy (metaphysics) are philosophical materials for Laruelle's science of philosophy or non-philosophy. Laruelle does not seek a democracy to come, but understands these different thoughts as democracy of thought: all thoughts equal and unifacially turned not towards a democracy to come, but a future.

Keywords: Derrida; Laruelle; Hermeneutics; non-philosophy; philosophy.

\section{Introduction}

To respond is what ordinary $\operatorname{man}^{1}$ (Laruelle 2013a:246ff.) does; it is part and parcel, one could say, of lived experience. For example, when reading two or more philosophers, it seems as if the only thing possible for an ordinary man to do is to respond to the two authors by comparing them. One could say that this would be the ordinary thing or even the normal thing to do, or as one so often says it would be the natural thing to do, as lived experience testifies this. My lived experience of reading these two authors confirms this: whilst reading, I had this intense desire or need to figure out where or how Laruelle and Derrida are similar and where and how they differ, and by figuring that out I could make sense of them. The need was driven by the idea that once I had them figured out, I could order them and place them into my world of meaning, sense and understanding. When reading different authors, one inevitably begins to compare them with each other, especially if they are writing about similar topics or themes.

Ordinary man responds - responds to the world as he or she experiences it, responds to texts that he or she reads, responds to other people, animals, nature, etc. Ordinary man responds to that which is perceived as given, that which is present to him or her, that which is unconcealed to him or her. What an ordinary man does not realise is that what is present to him or her is not presence but is a sign or a trace, or rather - the present, ordinary man's lived experience - is a trace of a trace (Derrida 1982:24).

\section{How to respond?}

Derrida in Passions: 'An oblique offering' (1995a) reflects about the challenges of responding, and specifically responding to texts as they are believed to be presented to one. In that specific essay, he was asked to respond to his own texts, to take responsibility for a body of texts written by him, as well as respond to texts of 12 friends who in turn have all responded to various texts written by Derrida. In reflecting about this request to respond, and to do so responsibly, he realises the impossibility thereof. He gives four good reasons not to respond, and then likewise four good reasons why it would be impossible not to respond (Derrida 1995a:18-22). The two sets of four reasons given both for and against cancel each other, and therefore, with the realisation that one cannot choose between these two, it remains undecided. Derrida argues that it is exactly this undecidability that is necessary for choice and for action: the impossible possibility of responding responsibly, and yet that is the only thing possible to do. It is also the thing that the ordinary man does: he or she responds, and one believes oneself to be responding to what the text actually says, or what reality actually is.

1.I am specifically using Laruelle's concept of ordinary man, with which I do not intend to be gender specific, but to link it to Laruelle's thoughts by using his term. 
This would be the only thing possible to do, the necessary thing to do.

This is what an ordinary man does, he or she responds. How does one respond? Does one respond like Derrida's specialist or as the specialist is translated in the German translation, Wissenschaftler (Derrida 2000:17), who 'seizes upon this work, assuming that someone has not presented him with it (something we will never know)' (Derrida 1995a:3) by 'believing he can recognize in it the ritualized unfolding of a ceremony, or even a liturgy, and this becomes a theme, an object of analysis for him' (Derrida 1995a:3)?

The Wissenschaftler, who specialises in ritual studies, seizes upon this work, that is, if it has not been presented to him, and he believes that it is all about ritual. This is for the ordinary Wissenschaftler the most ordinary and 'natural' thing to do in his or her lived experience of being a Wissenschaftler, specialising in the field of ritual studies or liturgical studies. It is the way he or she responds, the ordinary everyday response to that which is given to him or her, that which is present or presented to him or her, that is, if he or she has not seized it.

As Derrida seems to be arguing in the essay, it might be the necessary (possible) thing to do, yet it remains the impossible thing to do, at least to do it sufficiently responsibly (Derrida 1995a:22-23). Therefore, one could perhaps speak about the necessary but insufficient thing to do.

Why is it necessary (possible) and yet insufficient (impossible)?

\section{Impossible possibility of responding, yet the only thing possible to do}

One may take up the challenge presented in this article as an example: I am presented with two authors, both have written numerous texts. Maybe I am presented with a selection of their texts, that is, if I did not seize upon their texts, as it was I who consciously or unconsciously chose which texts to read. I selected from their body of texts, texts that I handpicked for a particular reason, or maybe a selection of their texts were presented to me by chance or fate. Maybe a selection of their texts came across my path, and I did not consciously or specifically select any particular text but took that which was presented to me by chance, as one says.

The texts presented (given), or seized, are present to me, and the ordinary, lived thing to do is to compare them. Yet as any ordinary man will soon realise there are numerous possible comparable themes, each of these themes would indeed have offered themselves, given themselves, as effects of these texts, that is, if I did not seize them from the texts. Who gave these themes? Did the texts give, or did I take (seize) them in the sense that I gave them? Did the texts give to me these themes, or did I give the texts these themes? Did I receive the themes from the texts or did the text receive the themes from me?
How will one know who gave and who or what received? How would we ever know if or what the difference is between giving and receiving?

This is what ordinary man does. It is what Laruelle himself did: when presented with the texts of Derrida, or when he seized the texts of Derrida, he compared them. He did the ordinary thing, that is, what any ordinary man would do - he responded to Derrida at various times in his life, comparing his own thoughts with that of Derrida. Each time he responded differently. In the early works of Laruelle (2010), the Philosophies of Difference, he grouped Derrida together with all other philosophers of difference.

Laruelle received (if he did not seize a theme) philosophers of difference from a large body of texts and their corresponding philosophers, who could, in turn, be given (or one could receive from the body) another name, namely, that of contemporary continental philosophers. These numerous texts by numerous philosophers were presented to him as a body of texts, grouped together by a dominant abstraction, for example, as contemporary philosophers. This was offered to him (presented to him, given to him), that is, if Laruelle had not seized upon this body of texts under the theme of contemporary philosophers. This body of texts enabled him (had the effect) to identify a theme and thereby to differentiate, cut from this body of texts via a decision, the philosophers of difference, that is, if he did not seize these texts in the name of the idea of philosophers of difference. Brassier (2003:27) in turn received, that is if he did not seize, from Laruelle's interpretation of Derrida, or Laruelle's reception of Derrida, if they both did not seize upon these texts, the idea that Derrida is a philosopher of difference, as according to Brasier, his thought is based on a non-relation-relation between language and the Other.

Slightly later, Laruelle and Derrida are in conversation with each other (Laruelle 2012c). They respond to each other and accuse each other, or each other's philosophy or nonphilosophy, of a certain violence.

Laruelle responds, once more, at an even later stage of his life's work to the work of Derrida, where he commends Derrida as the philosopher who had gone the furthest. There in that place, during the later stages of his life and work, Laruelle received from Derrida's work, that is, if he did not seize it, the idea of a restrained deconstruction, and he responds with his idea or theme of a general deconstruction (Laruelle 2013a:184-210).

Being an ordinary man, I received from their numerous texts various gifts, which I believe were given to me, presented to me, that is, if I did not seize it. Were they gifts, or did I steal it from their texts, as I seized upon the texts in the hope to be able to differentiate - to differentiate, on the basis of a theme or idea by taking or making a decision - with which I could cut into their body of texts and divide (differentiate) it into neat compartments of differences and/or identities or similarities? 
I needed to differentiate, to cut via a decision into this body of texts, so that I could organise this body without organs (see Deleuze \& Guattari 2011) into neat categories (organs or themes) with clearly comparable and significant subjects (themes), so that I could make sense of this body of texts without themes.

Only after organising these texts into significant subjects (themes) would it have been possible to distinguish them, identify the differences between them or, at least, identify where they are in close proximity to each other. Yet, this ordinary response became a nightmare, as every time I thought I had received or seized (I am never quite sure which of these two it is) a theme that clearly distinguished them or clearly identified the similarities between them, this theme was disturbed.

It was disturbed because I wanted to be a responsible reader or because I wanted my response to be responsible and therefore I wanted to ensure that my identified theme, or the theme that their texts had given me, was watertight and would remain consistent even if I read another text or read the texts once more, but then, the theme was disturbed.

I am not sure if it was a sense of responsibility or my narcissism that wanted my identified theme or these themes (given or received) (on the basis of which a differentiation or clear identification of similarities was possible) to be absolutely certain. I wanted to ensure, be responsible, that my clear differentiation or identification would stand the test of further reading, and, therefore, I read more or one more time, one more article, one more book, and my theme of differentiation or theme of identification of similarities was brutally disturbed and disrupted by that which did not fit into my theme, my abstraction (see Derrida 1995c:119f.).

My theme which I had received or given was disturbed, maybe haunted, by traces of an-other reading or an-other text, or the possible other themes these texts had to offer (give), or what could be seized from these texts, and that haunted my theme, haunted it with différance.

What ordinary man, and ordinary me, does or did not realise is that although these comparisons are possible and even necessary, for how else do we make sense of the world of philosophy and non-philosophy, these comparisons are insufficient and impossible. Yet, although they are impossible, it is the only thing possible to do.

Why is this? Why is it the only thing possible to do and yet impossible, as any attempt will reveal? It is impossible, as my attempt soon proved, that any such comparison will soon end in a circularity of receiving and giving not only between myself and the texts, but the texts of Derrida giving and receiving texts of Laruelle and vice versa. In the end, all one is left with is a Rhizomatic (Deleuze \& Guattari 2011) root system of intertwined themes of giving and receiving and the impossibility of escaping, as any attempt of tracing a line of escape is only recaptured.
This, no longer knowing if I am receiving from the text or if I am giving the texts a theme, reminded me of Derrida's reflection, or was it Plato's reflection or Socrates' reflection on Khöra, in the context of the text named Timaeus. The essay Khorra (Derrida 1995c) could be interpreted as Derrida's reflection of what Plato's text gave Derrida to reflect upon, or what Derrida seized from Plato's text. But wait, the Rhizome is more complex than that: is it my reflection of what I believe Derrida's text, Khōra (Derrida 1995c), had given me, which in turn is believed to be a reflection of what Derrida believed Plato's text, Timaeus, had given him to reflect upon or respond to, which in turn is what Plato wants us to believe is based on what he received from Socrates, who in turn argues that he, pretending to be like those who pretend to have place, so as to give his place to those who have place, so that he (Socrates) can receive from them what is taking place? This belief could also be turned around - it could also be the meaning that each reader gave to the text. Would we ever know which of the two it is - receiving or giving? - and is that not what this text, Khōra, is all about? Is it what khorra is all about, did I receive this from that text or is it what I am giving to that text in the belief that it is also what Derrida gave to that text?

Can this be avoided? Can one get out of this uncertainty between receiving and giving? Maybe only Heidegger's last God can save us: a last God who is beyond all this receiving and giving or a combination of the two or something in between? Is there not a last God who can clarify the true meaning of the text? If not a god, then at least an Egyptian priest, who has read the writing on the wall? Or will one always remain a child, as the priest tells Solon, that the Greeks will always remain children as they do not have writing and are dependent on myths (see Derrida 1995c:114f.)?

One cannot get out to get a God's eye view, but one can be conscious of abstraction, the receiving-giving, and by being conscious thereof (have theoretical knowledge thereof), that might change things slightly. It will not offer a line of escape, but it can open things up slightly, maybe open things up in the sense of a democracy of thought - to realise that all these abstractions are equal, as they are equally determined in the last instance by the text. Or they are all equal (all equally literature) as they are equally caught between receivinggiving, which can be, if one wanted to give it a name, the play of différance or play of khōra.

Caputo (1997:40) argues that khōra might be a good surname of différance.

One can either be conscious thereof as in a practice of nonphilosophy, or one can be conscious thereof, as in being conscious that one's responses, although the only thing possible to do, impossible, as they are always abstractions. This realisation does not offer a way out, but it does bring with it a sense of humility.

So ordinary man is asked not to take a position regarding these two authors, for example, but rather a posture of humility, not a posture towards the authors, but a posture 
with regard to his or her own abstraction (the only thing possible to do whilst being impossible). One could say a posture of humility not over against life, but a posture in life, in the lived. One might be tempted to say ordinary man must take a step back and get a clear view of what is happening, but take a step back to where? There is no outside view; there is no God's eye view, no outside position that would not again be based on a philosophical decision, which would lead to an abstraction.

Laruelle argues that to take a position (Laruelle 2012b:265f.), to try and position oneself outside of this play between reception and giving, would only be possible via a philosophical decision and therefore only one more abstraction (philo-fiction).

Therefore, he suggests a transcendental practice (Laruelle 2012a:148), a posture towards this necessary but insufficient comparison of, for example, these two authors.

This would be a practice of non-philosophy. Would this practice have certain similarities with a practice or rather a witnessing, or giving testimony to, auto-deconstruction? Ordinary man cannot stop himself or herself receiving (or seizing) something to compare, and here I go again trying to compare, this time, the practice of non-philosophy and the witnessing of auto-deconstruction.

Derrida does not necessarily, in my abstraction, take a posture or a position, but takes a stance in the text, as he knows there is no step out; there is no position outside, so he takes a stand in the text, reflecting about the impossible possibility yet it being the only thing possible to do. Khöra gives place to taking place and receives place for taking place, but without being any of these places or any of these givers or receivers of place. Abstraction takes place, and it takes place with ordinary man, in the ordinary lived experience. It cannot be avoided, but one can be conscious thereof. Can ordinary man become aware of the impossibility thereof and thereby take a new posture to the necessary but insufficient possibility thereof?

This is my necessary (possible) abstraction of Derrida's three essays, yet aware of the impossibility, that is, the insufficiency thereof, but this is all I can do: it is the only thing possible.

A sensitivity to the abstractions that are, and that these abstractions only are, because they cover over certain other voices in the text (but these other voices and possible gifts that could also be given by the text or given by the reader) are what disturb the abstraction, haunt the abstraction. If one is sensitive to that, one is also sensitive to a certain democracy to come, that is, to the other voices that need to be heard, which is also a justice to come, giving place to those who have not been given place, a democracy that is only possible if literature, or abstraction, is not censored (see Derrida 1995a:28-29), as there should be freedom of speech and any voice has a right to be heard and not only the dominant abstractions.
Laruelle's posture of non-philosophy takes a science-like look at philosophy as to why this is the case.

Both Derrida and Laruelle give reasons as to why this is the case. I will not return to a comparison, but rather give a reading of them together, thereby not being a Wissenschaftler, who seizes upon a work, but a Wissens-Schaffer, as someone who consciously is creating (Schaffen) with this material: the themes, given to the texts or received from the texts. A Schaffen is created with the material that I believe the texts of these two authors have given me, or I gave the texts, in the full knowledge that it is an abstraction, but a conscious one, consciously abstracting, creating, Schaffen, that is, a fiction. I will focus on Derrida's interpretation or rather reflection on khōra (Derrida 1995c) and use it together with Laruelle's theoretical or transcendental practice of non-philosophy and create my own conscious abstraction or philo-fiction.

\section{Giving-receiving a heretical identity}

Let us call the texts of Derrida or Laruelle that I am reading, the Real (the Real-Texts) and think of them in the light of khorra (place them into khōra), as that which gives but without givenness, that which receives but without being identified by that which it receives, as it remains foreclosed to thought. Laruelle's Real or One are philosophical functions and do not refer to anything specific (see Smith 2016:70). The texts of Laruelle and Derrida have given certain themes to me, that is, if I have not seized them in my attempt um sie zu ergreifen in einen Begriff. They are given but without givenness, and I have received them. Yet, what have I received? What have I received, which I did not create or give? Can one in khōra, if one ever is in khōra, distinguish between receiving and giving or are these two a heretical identity as Laruelle (2012b:268) argues?

I have received my own creation (what I gave), namely my abstraction. I have received that which I have given to the text and therefore the received and the given are heretically identical and yet both determined in the last instance by the texts. Yet, what the Real-Texts say remains foreclosed to thought (Text-in-Text).

I read the texts and understand them via an abstraction that I have given to the text (the meaning I have given to the text), believing that this meaning is what I have received from the texts. The abstraction is that which has been 'extended over all the folds of the text, of its ruses, overdeterminations, and reserves, which the abstraction will come to cover up and dissimulate' (Derrida 1995c:119-120).

How have I received them, which is how have I given them? I have received them, as if they (the texts) have given me something. This something is received, without question by ordinary man, as he or she believes they are receiving from the text its true meaning, which is believed to be the meaning of the text, as if this is the true meaning of these texts, unquestioningly given axiomatic. 
Laruelle tries to make sense of this heretical identity of, in my terms, receiving and giving, with his idea of cloning (Laruelle 2013b:pos 5904 of 7408). Laruelle says that the matrix of nonphilosophy is not a speaking-thinking-of-the-One or a speaking-thinking-of-the-Non-One, but it is a 'speakingthinking-according-to-the-One' (Laruelle 2012a:30). It is the One (text) that gives, like khōra gives, but gives without givenness. The abstraction (which is receiving-giving) is not arbitrary, but it is a certain effect of the text; it is given in the last instance by the text, determined in the last instance by the text. If there were no texts by Derrida and Laruelle, this essay would not exist either, so this text is determined in the last instance by Derrida and Laruelle texts, as all texts responding to these texts are determined in the last instance by these texts.

This according-to-the-One is the important difference, as a thinking-speaking (language) according-to-the-One is not and cannot be a relation of synthesis, fusion or logos, as Laruelle (2012a) identifies:

between the Real and language, the One and Being. It is a relation determined by a non-relation, a unilateral duality, and more profoundly a non-relation determined by the lack-of-relation to the Real. (p. 30)

There are two movements that can be understood as either the giving by the text or the giving by the reader. Laruelle refers to these two movements as axiomatic and theorematic, or as force and force-of-thought.

The force of the text gives the effect of the text, the gift of the text. Derrida speaks of the abstraction which is taken (received) from the text; there is a certain force (effect of the text) in the text. As Derrida (1995c) points out:

'Platonism' is thus certainly one of the effects of the texts signed by Plato, for a long time, and for necessary reason, the dominant effect, but this effect is always turned back against the text. (p. 120)

The question is how to think the effects of the texts and for necessary reason, together.

Laruelle tries to understand this relationship as a unilateral duality.

It is a non-relation, a 'unilateral duality' (Laruelle 2012b:290). A unidirectional movement, given and determined in the last instance by the Real, in this case, determined in the last instance by the text 'itself', which is foreclosed to thought, like khorra. Laruelle argues that it is in this context of unilaterality that philosophy functions as symptom. Philosophy functions as symptom or as language that is forced by the Real (Laruelle 2012a:70).

Non-philosophy does not try and undo this 'fact of language' via an antithetical style of argument, but via unilateral style (Laruelle 2012a:71). It does not propose a Real prior to the Realof-philosophy, but an in-Real where all these different terms coming from their respective thought-worlds (logocentricworlds) are all equally unilaterally determined in the last instance by the Real or One or Man-in-Man or One-in-One.
Again, it is necessary to use terms to come to grips ( $u m z u$ ergreifen) with that which gives to thought, but as a givenwithout-givenness. Laruelle refers to these terms as nonlanguage or the 'tongue' of non-philosophy (Laruelle 2012a:88).

The text itself remains foreclosed to thought, khōra cannot be thought or identified.

The force of the text that gives, to thought, yet that which is given and received is emplaced within khora, and thereby they are displaced (Laruelle 2013a:130).

The abstraction is received as it is given (effect of the Text) by the Text, and yet it is also received by the text as it is given by the reader, the abstraction, and very good reasons are given as to why this is the true meaning (abstraction) of the text. The reasons that are given can be described as the force-of-thought; reasons are offered to 'prove' the meaning of a text, based on a transcendental decision (identified by the specialist who knows what a text means). A text is understood and, therefore, the force-of-thought gives the reason(s) why this is the 'correct' meaning of the text: this is what the text says. The transcendental decision links or unlinks the abstraction to or from the text or the thought to or from the Real.

In a sense, two movements: one, the force of the text (effect of the text), the meaning a text offers (gives) which gives an abstraction and then the abstraction in turn is understood (force-of-thought) as the interpretation of a text, with reasons given, on the basis of some or other philosophical decisions or transcendental index as Badiou (2009:219f.) might say, as the meaning of the text and therefore gives the texts a specific meaning. The reader receives from the text a force (effect of the text, that which the texts gives) an axiom. The text receives from the reader a meaning, that which the reader gives on the basis of some or other philosophical decision (theory) - a theory of how it is possible to determine the meaning of texts or the meaning of the Real. These theories are transcendental, not immanent to the text itself.

The reader becomes the receiver and receives by giving meaning based on a philosophical decision. In other words, the meaning of the text (what a text is) appears based on a transcendental index that allows a text's meaning to appear in the logic of a particular world of understanding.

Then the receiver receives the given (effect of the text, force of the text) - the necessary (but insufficient) abstraction. The reader has given the text a certain meaning, theme, identity and can clearly articulate (give) good reasons for why this is the correct abstraction (meaning or theme) of the text, correct interpretation of the text, the force-of-thought. This explanation is possible via a philosophical decision or transcendental index. It is via the force-of-thought that the reader gives to the text a specific meaning, which he or she thinks they have received from the text, but without the Text becoming that which is given to it, the Text remains foreclosed to thought. 
Khōra gives and khōra receives but remains undisturbed in a sense by both giving and receiving, and in that sense remains foreclosed to thought.

The giving of the text (effect of the text or force of the text) is heretically identical to the force-of-thought - the reasons given concerning the meaning of the text. They are heretically identical, but not as an identity of synthesis or difference nor such that one can serve as an analysis of the other.

These two movements are heretically identical for Laruelle, as they are given as a unilateral duality determined in the last instance by the One or Real (Text).

If I had to give an abstraction of thinking Laruelle and Derrida together, specifically Derrida's thoughts in the three essays in On the Name, I would say it in another language:

\section{Das Wort vom Ort ist im Wort, von wo und worin Wort stattfindet.}

Das Wort vom Ort - the Ort [place] which gives and receives without being determined by that which it gives nor by that which it receives besides maybe in the last instance. That Ort, the place where things take place, such as thoughts, the speaking of language (Ereignis), the speaking of language where things (onto-logy) carry out a world (onto-logy), or cosmology as in the Timaeus, can be called khorra. Although kh $\mathrm{ra}$ does not name any thing or place, yet it is the place, without being a specific place, where all these things take place - wo sie stattfinden. Where do these things take place, the giving-receiving, or where do the two movements, force and force-of-thought, take place? They take place in the abstraction, der Ort ist im Wort, in the philo-fiction. There might even be a connection to Badiou (2009:39) here, namely, that onto-logy, that which is, can only appear within a certain logic (word) of the world of appearance (onto-logy). It can only appear in and through the word, the Ort im Wort. It is in the word or through the word that things appear, where they can take place (stattfinden). One is thus left with Word, or philo-fictions, abstractions, and these are as real as it gets. Ordinary man with his lived experience takes these as real (well, as real as it gets, or as real or as determined in the last instance by the Real).

But this Word, these philo-fictions, are not words at peace, but are words disturbed, haunted by that which is covered over in the abstraction.

Therefore, although one is left with philo-fictions and/or abstractions, this is the only thing an ordinary man can do, the only thing possible to do, the impossible, namely, to abstract, that is, create philo-fictions. Yet through the practice of non-philosophy orbecoming aware of infinite alternation between giving and receiving place as there is no outside text (Derrida 1997:158), no outside abstraction, becoming aware of this, but then not taking a position but rather a posture, could transform an ordinary man into a stranger subject (Laruelle 2012b:295-301).

\section{Posture of a stranger subject}

The stranger subject is not a stranger because she or he can stop out of fictions. He or she is always a subject of a particular world, a character in a particular fiction, but through the practice of non-philosophy - which is a theoretical practice - he or she understands that these are fictions, without the possibility of taking a position outside these fictions as there is no outside text. He or she takes a posture in the worlds of these fictions, but as a stranger, someone who is aware of the abstractions. He or she is a stranger not because they are outside (position), but because of a posture of humility in the various fictions.

What can the stranger subject hope for?

He or she cannot hope for a way out, as such a hope can only be based on a philosophical decision, that is, on a transcendental decision. He or she can hope for democracy of literature to come, literature that is less censored, that gives more and diverse voices a voice and in that sense literature that is more just. The stranger subject in this democracy of thought - radical democracy of philo-fictions where there are no better fictions, just more fictions - is not turned to an outside or an Other, but is unifacially turned to the future, ${ }^{2}$ with hope. This hope disturbs the fictions with more fictions to come - uncensored or rather less-censored fictions, where one fiction is as good as the other, determined in the last instance by the Real or Text. It is a utopia (non-place and nontime) that haunts the fictions. Are all fictions equal or are there better fictions? Bad fictions would be fictions that have no idea that they are fictions, they are over-confident and often absolute and with aspirations of universality. These could be master narratives, yet also slave narratives, as it is difficult to know who is a master and who is a slave. Bad fictions are fictions that consciously censor or exclude voices. Good fictions are not all-inclusive multicultural fictions, as these are also exclusive in their own way, but inclusive in the sense of being sensitive to their violence of exclusivity. Bad fictions would also be the relativist fictions where all stories are relative to their context of construction, or I could rather argue: all fictions are real, as real as it gets, and are determined in the last instance by the Real.

Let us create knowledge, determined in the last instance by the Real, but as stranger subjects, knowing one is a Wissensschaffer and not a scientist who discovers.

\section{Acknowledgements Competing interests}

The author declares that no competing interest exists.

\section{Author(s) contributions}

I declare that I am the sole author of this research article.

2.As Laruelle (2011:254) states: '... weak forcing, the minimal torsion exacted upon philosophy that is ultimately no longer reversible but uni-directional, consequently philosophy that is ultimately no longer reversible but uni-directional, consequently
a future'. See also Alkon and Gunjevic (2011:219). 


\section{Ethical consideration}

This article followed all ethical standards for a research without direct contact with human or animal subjects.

\section{Funding Information}

This research received no specific grant from any funding agency in the public, commercial, or not-for-profit sectors.

\section{Data Availability Statement}

Data sharing is not applicable to this article as no new data were created or analysed in this study.

\section{Disclaimer}

The views and opinions expressed in this article are those of the authors and do not necessarily reflect the official policy or position of any affiliated agency of the authors.

\section{References}

Alkon, G. \& Gunjevic, B., 2011, 'According to the identity of the real: The non philosophical thought of immanence', Synthesis Philosophica 51(1), 209-227.

Badiou, A., 2009, Logics of worlds: Being and event, 2, transl. A. Toscano, Continuum, London.
Brassier, R., 2003, 'Axiomatic heresy: The non-philosophy of François Laruelle', Radical Philosophy 121(Sept/Oct 2003), 24-35.

Caputo, J.D., 1997, The prayers and tears of Jacques Derrida: Religion without religion Indiana University Press, Indianapolis, IN. https://doi.org/10.2307/j.ctt2005rjr

Deleuze, G. \& Guattari, F., 2011, Thousand plateaus: Capitalism and schizophrenia, transl. B. Massumi, University of Minnesota Press, Minneapolis, MN.

Derrida, J., 1982, Margins of philiosophy, transl. A. Bass, Harvester, Brighton.

Derrida, J., 1995a, 'Passions: "An Oblique Offering"', in T. Dutoit (ed.), On the name, pp. 3-31, transl. D. Wood, Stanford University Press, Stanford, CA.

Derrida, J., 1995c, 'Khōra', in T. Dutoit (ed.), On the name, pp. 89-130, transl. I. McLeod, Stanford University Press, Stanford, CA.

Derrida, J., 1997, Of grammatology, transl. G.C. Spivak, John Hopkins Press, Baltimore, MD.

Derrida, J., 2000, Über den namen: Drei essays, aus dem Französischen von HansDieter Gondek und Markus Sedlaczek, Passagen Verlag, Wien.

Laruelle, F., 2010, Philosophies of difference: A critical introduction to non-philosophy, transl. R. Gangle, Continuum Books, London.

Laruelle, F., 2011, 'The generic as predicate and constant: Non-philosophy and materialism', in L. Bryant, N. Srnicek \& G. Harman (eds.), The speculative turn: Continental materialism and realism, re-press, Melbourne.

Laruelle, F., 2012a, Struggle and utopia at the end times of philosophy, transl. D.S. Burk \& A.P. Smith, Univocal, Minneapolis, MN.

Laruelle, F., 2012b, From decision to heresy: Experiments in non-standard thought, R. Mackay (ed.), Sequence Press, NY.

Laruelle, F., 2012c, 'Controversy over the possibility of a science of philosophy', in G. Alkon \& B. Gunjevic (eds.), The non-philosophy project: Essays by François Laruelle, pp. 74-92, Telos Press, New York.

Laruelle, F., 2013a, Philosophy and non-philosophy, transl. T. Adkins, Univocal, Minneapolis, MN.

Laruelle, F., 2013b, Principles of non-philosophy, transl. N. Rubczak \& A.P. Smith, Bloomsbury, London.

Smith, A.P., 2016, François Laruelle's principles of non-philosophy: A critical introduction and guide, Edinburgh University Press, Edinburgh. 